\title{
Converging Perspectives on Interest-Group Research in Europe and America
}

\author{
Christine Mahoney, Syracuse University \\ chmahone@maxwell.syr.edu
}

Frank R. Baumgartner, University of North Carolina, Chapel Hill

frank.baumgartner@gmail.com

Paper prepared for the European Union Studies Association bi-annual meeting,

Marina del Rey, LA, CA, USA. April 23-26, 2009 


\begin{abstract}
The European and American literatures on lobbying and interest groups developed largely separately in previous decades. Scholars developed different research foci with Europeans more commonly rooted in studies of policy systems and Americans more concerned with precise tactics of lobbying or on the membership calculus following from the work of Mancur Olson.

Recent developments in the study of interest groups in Europe suggest that the literatures have begun to be much more closely aligned, a development that can be expected to accelerate in the future. We focus on three major points of convergence, giving illustrations and empirical evidence from the literature on each. First is the impact of governmental structures on the growth and development of national interest-group systems. Using examples from the US and the EU, we discuss the coevolution of groups and the state. Looking both over time and across issue-domains, groups are more active when and where the state is more active. Second, we look at the impact of government structures on the locus of advocacy. Originally explored in the U.S. context, multi-level governance structures in European settings have led to consideration of the concept of venue-shopping. Finally, we discuss the impact of government structures on advocacy behaviors, showing how groups in both systems adjust their lobbying strategies to their political context. Our review of findings and empirical developments in these three areas of interest-group research suggests that the study of groups, long divided by different perspectives may begin to benefit from substantially more convergence of research interests.
\end{abstract}




\section{Introduction}

As interest-group scholars on both sides of the Atlantic pay greater attention to similar research questions, the centrality of institutions to understanding advocacy is becoming more and more evident. The adoption of an explicitly comparative research framework allows a full appreciation of how institutions of governance influence interest-group mobilization, the locus of interest-group activity, and the character of that activity. We explore the mutual impact of groups and government structures in these three areas, using examples from the US and EUbased research on groups, and we discuss future research priorities.

The European and American literatures on lobbying and interest groups developed substantially independently in previous decades but have more in common today. With some notable exceptions, European and American scholars developed different research foci with Europeans more often rooted in studies of policy systems and Americans more concerned with precise tactics of lobbying, the role of money in the political system, or on mobilization and the membership calculus following from the work of Mancur Olson. The US and European literatures on interest groups were once quite similar; in the generation of David Truman, Robert Dahl, and the classic pluralists, studies were clearly focused on the policy impact of interest groups. US and European scholars certainly had no reason to agree on the substantive conclusions of how much influence groups wielded in the process, but common questions were being addressed, and these largely revolved around the interactions among groups and officials within the state.

Beginning in the 1960s the literatures diverged significantly, however, as US scholars became preoccupied with Olsonian dilemmas of how groups mobilized or failed to do so. By mapping out the various incentives and disincentives to mobilization, this perspective implied, 
we could understand the overall biases and dynamics of the national interest-group population. The study of group formation and maintenance came to dominate to the expense of studies of group interactions with the state (for a review of this literature, see Baumgartner and Leech 1998). The study of groups in the US became the study of mobilization dynamics; this focus was never as predominant in Europe.

Trends toward divergence were not absolute; US scholars continued to be interested in such phenomena as policy subsystems, issue-networks, and policy communities (Cater 1964; Fritschler 1975; Heclo 1978). This literature referred substantially to the similar British literature on policy networks (see for examples Jordan and Richardson 1987; Smith 1993) and in any case was clearly focused on the relations and interactions between private and state actors. In this sense the work was fully concordant with European perspectives. Similarly, a number of European scholars addressed the mobilization question, in particular as it related to the literature on social movements and social movement organizations (SMOs); this literature fit in quite easily with the US literature on the topic, mostly in sociology (see for examples Della Porta, Kriesi and Rucht, 1999, Della Porta and Diani 1999; Kriesi et al. 1992). In spite of these areas of overlap, there were important areas of difference, and on the whole European scholars in the 1970s and 1980s referred to a different set of research questions and to a different set of core citations, than their American counterparts.

For reasons that are perhaps related to different methods of political financing and reporting, the European literature never developed the focus on financial issues as had occurred in the US. Rather, mapping out the varieties of corporatism, or "national styles of policymaking," was the agenda (see Schmitter 1974; Schmitter and Lehmbruch 1979; Lehmbruch and Schmitter 1982). Of course not all systems were seen to be varieties of corporatism as scholars from 
various countries assessed their systems as consociational, statist, pluralist, or with other descriptors; further this literature on national styles of policymaking has come under stress with increased globalization, sectoral variation, multi-level governance, and Europeanization of policies. Our point is not that a corporatist label applied to any particular country; rather, European scholars were engaged in an effort to describe patterns of group-state relations that had no parallel in the US.

There were of course some notable exceptions to the general trend of European scholarship to focus on these questions. Grant Jordan’s work on policy networks is a good example of a broader conception of the policy process than only formal interactions (Jordan and Richardson 1987; see also Smith 1993). Important works took an explicitly comparative framework (for examples see Immergut 1992; Jordan and Maloney 1999; Knoke et al. 1996; Katzenstein, 1985; Schneider et al., 2006) or a broader conceptual framework (such as the work of Mayntz and Scharpf 1975). Similarly, the developing literature on multi-level governance structures strongly implied that systems of governance were much more complicated than any corporatist analysis could allow. So our point is not that Europeans were uniformly conducting research projects that were disjointed from the US research agenda (or that, if they were, this would have been a negative development); of course any such generalization could not be maintained. The point is simpler, that in important ways and with many exceptions, the European literature on national policymaking styles often did not engage with the US literature; the two scholarly communities operated substantially in separate spheres from at least the 1970s and well into the 1990s, and substantially less so today.

Recent years have seen a convergence in American and European interest-group studies which parallels a more general trend among political scientists considering transatlantic 
phenomena. This is due to both changes in academe and changes in the real world. On the first point, scholars today are more likely to share their research through publication in international journals and participating in international networks, and these networks increasingly incorporate US as well as European scholars. This facilitates the spread of theories and approaches across the Atlantic as we have seen in application of rational choice, neo-institutional, and principal-agent analyses, mobilization theories, political opportunity structures, among other concepts. This convergence of US and EU interest-group studies is reinforced by changes in the real world. Transnational corporations, international NGOs, and global government-relations firms are operating in both Washington and Brussels to respond to the challenges and opportunities of globalization and to contribute to the development of intergovernmental initiatives to increase transatlantic harmonization in legislation and regulation. The increased interaction of both transatlantic players as well as scholars has led to fusion of US and EU interest-group studies, a development which is likely to provide deeper insight into group behavior in both systems.

We focus on three major points of convergence, giving illustrations and empirical evidence from the literature on each. Some lines of research have been developing independently but simultaneously in both systems and clearly indicate similarities across systems; in other areas EU developments precede substantial development of the ideas in the US; and finally we see theories from the US shedding light on EU questions. The first area of research convergence is the impact of governmental structures on the growth and development of interest-group systems. Using examples from the US and the EU, we discuss the co-evolution of groups and the state. Looking both over time and across issue-domains, groups are more active when and where the state is more active. Looking across systems allows us to investigate future how variations in state development can influence group system development. 
The second area is the impact of government structures on the locus of advocacy. Interest groups seeking to influence public policy must seriously consider the venues in which they argue their positions; often there is some flexibility in which institutional unit may be targeted. Some venues may be more hospitable than others. The development of multi-level governance structures in Europe has produced entirely new strata of institutions and multiplied the venues groups can target. This multi-level structure has led EU scholars to consider the role of "venueshopping” and alerts US group scholars to re-consider the concept and potentially broaden its application to different levels of government in the US. Of course the opportunities and constraints of multi-level governance in the European context differ in important ways from the US system of federalism combined with separation of powers, so theories cannot be exported without care.

Finally, government structures themselves strongly affect advocacy behaviors, causing groups to adjust to fit the institutional context within which they work. Investigating advocacyrelated phenomena that have traditionally been the focus of US group scholars in more than one political system allows scholars to take the role of institutional design on advocacy more seriously and study it more systematically. Research on lobbying positions, tactics, argumentation, coalition action and other topics in both Washington and Brussels demonstrates the central role of institutional design. Our review of findings and empirical developments in these three areas of interest-group research suggests that the study of groups, long divided by different perspectives may begin to benefit substantially from this increased convergence of research interests. 


\section{The Co-evolution of Groups and the State}

It is rare to have the opportunity to observe a political system develop from its birth; it is even rarer to have solid empirical data on the process. EU scholars, especially integration theorists, have long recognized their fortunate position for the study of political development. While EU scholars may have been more conscious about the dynamic nature of their subject of study, US scholars too have benefited from the availability of data over the past 60 years documenting both the growth of the state and of the group system. In both systems scholars have found, over time, the size of the government to grow (in budgets, personnel, bureaus, and departments), the breadth of policy activity of the government to expand, and the power of the central government to increase. This government growth was matched in both polities by the steady growth of the interest-group system.

Tracing the development of government activity and group formation in US over the post-WWII period, Baumgartner and Jones (1993) found that the number of associations grew substantially over the post-war period and in particular that the diversity of such organizations increased as well (see chapter 9, Figures 9.1 and 9.2). The US political system generated a greater range of interest groups, a much broader constellation of forces than only trade- and business-related groups as had dominated in the 1940s and 1950s. Through the social movements of the 1960s and the "interest-group explosion" that followed, a much wider range of interests were mobilized into the political system. These effects, of course, were strongly related to changes in the political system itself-the period during which the group system grew most substantially is the same as when government itself grew the most quickly, and a decline in the pace of growth of government after the late-1970s in the US is also reflected in a reduction in the growth rate of the group system. 
In previous work, we investigated these dynamics in particular issue-domains, demonstrating that groups and government actions were closely linked in the areas of human rights, civil rights, the elderly, women’s issues, and the environment (Baumgartner and Mahoney 2004). The rise of a variety of new social issues on the governmental agenda, we argued, was related to the development of the interest-group system in those same areas. Other quantitative projects have attacked the same question from different approaches. Beth Leech and colleagues (2005) analyzed patterns of interest-group mobilization as reported in Lobby Disclosure Reports filed with the US Senate from 1996 to 2000. Correlating the number of groups reporting policyrelated lobbying activity in each of the 74 issue-areas with the numbers of congressional hearings, they found that increased hearings activity systematically encouraged the mobilization of more lobbying groups. This finding of government mobilization was over and above the impact of economic mobilization and government spending in their study. Government activity, whether it be welcome or unwelcome, mobilizes interest groups to demand more or to protect their interests against further government activities. Recently, Baumgartner, Gray, and Lowery (2009) have used similar a methodology to analyze the linkages between government activities at the federal level and interest-group mobilization at the state level. Controlling for other factors encouraging state-level interest-group mobilization (including variables previously identified in Gray and Lowery’s on-going research on group mobilization such as the state economy, political uncertainty, and ideology), they found robust findings that national-level policy activities both directly and indirectly encourage the subsequent mobilization of groups in the states. The direct linkage was simply by encouraging groups to become active in those same issue areas in the states in the following year. The indirect effect, in addition to this one, stemmed from national 
policy activities leading to subsequent state-level legislative activity, and this in turn affecting the mobilization of groups.

Many qualitative studies have investigated the give-and-take between the development of powerful social mobilizations and new public bureaucracies, agencies, or distributional programs. Skocpol's (1992) original work on the development of the social welfare system, with its emphasis on war veterans after the US Civil War, is a case in point. Similarly, Campbell's (2005) analysis of the development of political activism among the elderly in response to the development of the social security system showed that those seniors with greater financial reliance on social security benefits were more likely to become and remain active in politics. Government policies, she found, could profoundly affect the political behavior of those most affected by them, which in this case is those with fewer financial means who are therefore most reliant on their social security checks. The elderly have not been mobilized only by the American Association of Retired Persons (AARP—-the world's largest voluntary association); in fact they have been mobilized into the AARP and into political life more generally by the very government policies that they seek to enhance. A third example is Mettler's (2005) study of the "greatest generation,” mobilized into distinctive patterns of political activity through its history of benefiting from the GI Bill and other distributive policies aimed at rewarding the returning veterans of World War Two. In sum, a wide variety of evidence from the US suggests that groups and the state co-evolve at the national level and with important implications at lower levels of government as well. These studies are longitudinal, cross-sectional, qualitative, and quantitative.

Similar patterns have been documented in the European Union; as the EU's competencies expanded with the adoption of successive European treaties, the number of groups increased as 
well. Fligstein and Stone-Sweet (2002) demonstrate how a co-evolution system has been at play throughout the history of the EU. They argue a self-sustaining causal system has driven the development of the EU and its group system, and they present data on intra-EU trade, litigation on European law, EU legislation, and EU group formation, all of which have mushroomed over the post-war period. Their findings show that group formation is driven by government activity both in the courts and by the legislature and at the same time group formation drives more government activity in legislation. Wolfgang Wessels similarly sees a co-evolution of groups and government in the EU in his data and similarly argues the process is self-sustaining and irreversible. He notes "fundamental trends of an evolving system can be identified by a set of five indicators: the output of binding decisions, the scope of public policies, transfer of competencies, institutional and procedural patterns, as well as the involvement and influence by intermediary groups. These all point at processes of considerable growth and differentiation from the 1960s to the 1990s" (Wessels 1997, 275). His data show that as EU activity has grown so too has the size of the non-governmental actor community in Brussels.

Bernhard Wessels also investigates the relationship between state and group development noting that the "history of interest-group systems in nation states shows that interest-group formation has often responded to changes in the allocation of authoritative competencies” (2004, 199). Wessels suggests that groups may either organize in anticipation of coming policy expansion, or in reaction to changes in EU power and that "anticipation and reaction can lead to the co-evolution of interest-groups and the state” $(2004,200)$. Wessels' time-series analysis considering group formation and major treaty changes shows strong evidence of groups forming in reaction to government growth, with particularly large increases in group formation after the establishment of the EEC in 1958, the Single European Act in 1987, the first level of the 
currency union, and the Masstricht Treaty” $(2004,202)$. He finds little support that groups were forming in anticipation of increased state activity.

Mahoney's data on group formation also show periods of increased growth in the EU interest-group system around periods of major treaty change. Figure 1 shows both cumulative and annual group formation data of all the organizations in the Commission's voluntary civil society registry CONECCS. The data make clear that group growth occurred in spurts, not gradually, and that it occurred both before and after treaty changes.

(Insert Figure 1 about here)

As in the US, government and group co-evolution is detectable not only in the aggregate but also when we consider state and group activity by sector. Mahoney (2004) demonstrates that there is a great deal of variation in group formation and activity across policy areas with the largest number of groups active in the areas of enterprise, the environment, social affairs and agriculture. In addition, high levels of group activity in a policy area correspond to government activity in an area as indicated by the resources allocated by EU institutions to each policy area (Mahoney 2004, 461). As EU institutions increasingly legislate and regulate within a particular policy area, affected interest groups increase their advocacy activities in that area. Jan Beyers, Rainer Eising, and William Maloney report similar findings in showing the development of EUregistered groups by policy area over time (2009).

There is a tendency to focus on the uniqueness of the EU system; however, the patterns we see in the EU mirror those we see in other polities. Considering the EU comparatively alerts us to these broader political phenomena. While it is true the EU is a unique hybrid system, many of the political processes that go on within the EU are seen in political systems generally. From the extant literature in both the US and the EU we know there is strong evidence that group 
growth and government growth go hand in hand. This can be detected in the aggregate and even more so when we disaggregate analysis by policy area. As governments grow and become active in new policy areas, naturally groups become mobilized. They may work to encourage further government activity, or they may mobilize to protest against or to counter the new state activities, but they often become involved in lobbying and active in the policy process as a result of government activity, not before it. Of course, group mobilization sometimes has the goal of generating new public policy initiatives, a process that can have subsequent feedback effects. In sum, no matter which political system we consider, the co-evolution of groups and the state is a common theme.

Of course, considerable work remains to be done both at the national and the EU level to elucidate these questions further and to determine the relative importance of various relationships. Do certain types of government activity lead to more group formation? Are some types of groups better able to prompt state activity? Is the process historically contingent? To accurately assess any questions related to this process it is necessary to collect time series data with detailed coding by policy area of all governmental and non-governmental activity indicators. On-going work relating to regular censuses of interest groups and measures of government activity are important priorities. These will provide the data to answer some of these questions more directly as well as the infrastructure to allow a wide range of quantitative and qualitative research projects explicitly making these linkages across several political systems.

\section{Evolving State Structures and the Locus of Advocacy}

As issues move on and off the political agendas of different levels of governance, advocates seeking to influence those issues must follow suit. Jurisdiction over a policy area may move up or down the hierarchy of a multi-level system. A previously local issue like gay marriage may 
become a federal issue in the US. A topic once under control of national governments, like factory emissions, may shift to fall under the competencies of the EU. Environmental regulations may be made in states such as California if state officials feel that the federal government is not acting aggressively enough; at other times, federal policies may force the states or groups may demand a single national standard in order to avoid a patchwork of different standards in different states. The concept of multi-level governance is central in EU research; indeed it is so common that it is commonly referred to as MLG. MLG is treated as a grand theory by some or, short of that, as an important approach to understanding an array of political phenomena. In the US, a similar body of research exists but under a different name. Students of federalism have questioned the most effective delineation of powers across local, state and federal levels of governance (Peterson 1981, 1995) and investigated variation across states (see Gray, Hanson and Jacob 1999 for an overview). The complexities of US federalism and EU multi-level governance are similar but the significance of multiple tiers of governance for understanding a whole range of political phenomena has received greater attention in EU studies, and of course the linkages among the levels of government are not the same. The EU does not have global jurisdiction whereas the US federal government is involved in a comprehensive array of policies and the US system combines separation of powers with federalism to a degree not seen in Europe. These differences, however, are not even as complete as they appear as the US also includes highly "federalized” issues (such as national defense) and highly localized ones (such as education). However, the limited jurisdiction of the EU and its greater focus in some areas of economic regulation than others is an important difference in practice. Federalism studies, or so called 'state and local politics' research, in the US on the other hand has proceeded quite divorced from much research on American national politics, even in similar policy areas. 
Scholars of advocacy and public policymaking in the US could learn from EU studies by incorporating the role of multiple layers of governance more fully into their research agendas.

In the EU research is being conducted on groups at both the national and supranational levels providing a better understanding of how European interests are navigating the EU multilevel system. Huge numbers of interests have mobilized at the supranational level and are engaging directly with the EU institutions. This has been well documented (Greenwood 1997; Mazey and Richardson 1993; Hix 2005) and includes business, trade, professional associations as well as citizen groups, institutions, companies, foundations and unions. Local and regional representations have moved to Brussels to bypass their national governments and appeal directly to the supranational institutions on a variety of issues (Keating and Hooghe 2001; Marks et al 2001). Beyers's (2004) data on 157 EU-level interest associations shows that these groups are using a rich repertoire of tactics combining inside or access strategies with outside or voice strategies. In a recent review article, Daviter (2007) emphasized the value of studying framing processes at the EU level. Research on framing can be closely connected with that dealing with interest-group strategies and policymaking processes at the European and national levels.

However, we also know that numerous interests remain active at the national level— either exclusively or as part of a multi-level strategy—as seen in additional work by Beyers comparing the access strategies of both national-level and EU-level interests (2002b). Eising (2004) finds that groups that are unable to gain access at the domestic level see that pattern reinforced at the supranational level. Grossman (2004) argues that there are barriers to EU-level activity and therefore it should not be assumed that organized interests will automatically mobilize at the supranational level. Presenting evidence from the banking sector, he showed that national-level organized interests focused on the national level of governance, hanging back 
from targeting the supranational institutions during the debates on economic monetary union (EMU) and the Single European Act (SEA). Grossman does not expect this always to hold, however - it is a transitional period during which interests learn about the new level of governance. The expectation then would be as the EU expands its activity in a certain area, organized interests would lag in targeting their advocacy toward the EU-level. This of course cannot speak to the situation in which the advocates are pushing to state activity in an area where the EU is not (yet) active. We may expect groups to adjust their strategies to newly developing levels of governance, as with the growth in competencies of the EU, but the speed at which groups might make these adjustments is an open empirical question. It is not that simple to establish a new lobbying office in a new city.

Lack of knowledge or familiarity with a level of governance however is not the only barrier to targeting a new level of governance as it emerges. Certain tactics and certain types of groups find they can be more effective at the local and national level. For example most social movement scholars considering social movement activity—manifestations, demonstrations, protests—related to EU issues have found that the majority of this form of political advocacy remains at the national and sub-national level (Marks and McAdam 1996; 1999; Bush and Semi 2001). In addition, outside lobbying has similarly remained at the national level. Kriesi and colleagues (2005) show that outside lobbying tactics remain largely focused at the national level. This is understandable considering the structure of the media system in Europe.

Group scholars in the US have been quite myopic in their focus on the federal level, though exceptions do exist. Gray and Lowery (1996) have been the primary scholars shedding light on the underdeveloped area of state-level interest-group processes. Several scholars including Gerber (1999) and Boehmke (2005) both investigate the role of groups in the states as 
these affect and are affected by referenda and initiative campaigns. A variety of studies investigate the roles of groups within particular issue domains in the 50 states, of course but such a review is beyond the scope of this paper.

Baumgartner and Jones’ (1993) discussion of “venue-shopping” has much to do with attempting to move issues to or away from the US federal government (though the concept also applies to seeking the intervention and authority of one federal agency rather than another). Shipan and Volden's (2006) analysis of inter-governmental dynamics in lobbying strategies in the case of anti-smoking legislation provides a recent example of an appreciation of the role of multi-level governance in US advocacy. Anti-smoking advocates focused on large cities depending on whether the surrounding state was open or closed to state-level regulation. Naturally, if state policies could be adopted, municipal-level regulations would be less important. Shipan and Volden's work provides important methodological lessons and a model for other work and also shows the importance of multi-level governance to scholars of the policy process in the US. Sarah Pralle (2006) demonstrates the importance of venue-shopping within the Canadian federal system in her analysis of environmental politics in that country; her work provides an excellent qualitative example for further research in the area. In an innovative design considering which interest groups are able to have their voices heard in the area of criminal justice policy, Miller (2008) shows the negative impact of the increasing federal role in crime control policy on the participation of local and neighborhood organizations. Local groups, which find it harder to garner substantial material resources, can and do participate at the local level, where barriers are quite low. However, they are rarely heard when similar issues are discussed at the state or national level, effectively leaving only police and criminal system professional organizations present when decisions are being made there. 
Taken together, the EU interest group literature which looks more explicitly at interest group activity at multiple tiers of governance, and the US literature, which while smaller, should be considering advocacy at the federal, state and local levels, we see further evidence of the benefits of cross-pollination of US and EU research. Future research in both the US and the EU on the process of venue-shopping, by which advocates seek out and engage with levels of governance that are more favorable to their cause, may be one avenue simultaneously to study advocacy at different layers of governance. Another framework that may elucidate how interest groups operate within multilevel systems is the concept of political opportunity structures borrowed from the social movement literature. Princen and Kerremans (2009) argue that a great deal of the research on EU interest groups including work on social movements, resource exchange and venue shopping, can fall under the umbrella of political opportunity structures. To understand when groups mobilize and succeed in their advocacy we have to consider the political opportunity structure within which they are operating - the number of access points, the openness of those access points, the design of the political institutions, and the state of the political climate. This relates back to the central argument of this article-comparative research approaches and research cross-pollination highlight the importance of institutional systems in understanding interest group behavior.

\section{Structural Effects on Advocacy Behavior}

The daily lobbying activities of interest groups — through which they attempt to promote their positions in the policymaking process - are of course important to understand if we hope to learn why political systems produce some public policies and not others. Scholars in both Europe and the US have increasingly recognized that lobbying behavior varies not just by organization but that the same organization will behave differently in different contexts as determined by the 
institutional structure and by the characteristics of a particular issue. Recognizing this interaction between institutions, issues, and interest-group characteristics only becomes possible when we move to a comparative research framework.

Mahoney (2008) demonstrates how institutional structures combine with issue-context and interest-group factors to determine advocacy behavior. Specifically, her analysis considers the role of three important institutional characteristics which vary across political systems. First, direct elections make policymakers more responsive to interest-group communications. Policymakers that face re-election directly by their constituents are highly aware of their electoral vulnerability (Mayhew 1974), attuned to information and argumentation that makes reference to their constituents' concerns, and responsive to advocacy tactics aimed at communicating information about constituent opinion. The positions of appointed policymakers on the other hand do not depend on the results of a coming election; such officials are not driven by the re-election motive, and are more attuned to information about policy feasibility and direct communications about policy details. For them, constituent opinion is not as vital as it is to politicians. Empirical evidence suggests that lobbyists targeting re-election-minded policymakers do indeed tailor their advocacy behavior — their argumentation and their lobbying tactics— to capitalize on that drive (Mahoney 2008).

Second, the institutional rules in the policymaking process including how policy proposals are introduced, how they are amended, and how they become law also constrain lobbyists. Advocates working in systems which allow for a great number of official policy proposals have the opportunity to advocate pro-actively for their preferred policy alternatives. Systems in which the number of policy proposals is restricted make it more difficult for advocates to propose new laws. Furthermore, the likelihood of a proposal surviving the policy 
process affects how lobbyists engage the issue. In systems where policy change is unlikely, where bills often die due to institutional rules, lobbyists opposed to a proposal can easily protect the status quo. In systems where policy proposals tend (eventually) to be enacted, lobbyists opposed to a proposal must work to modify a dossier at the margins. Data on the approach of lobbyists in a wide range of policy disputes, some trying to bring about new laws, some trying to amend and tweak new proposals, and some trying to block dossiers full-out, demonstrates that the rules of the policymaking process shape the tactics lobbyists select (Mahoney 2008). EUbased lobbying, for example, was significantly more about revising the content of commission proposals, based on common knowledge that some form of the proposal was highly likely to be adopted at some point, whereas US-based lobbying was much more likely to focus on a strategy of "killing" the proposal since most proposals, even those seriously discussed, are not adopted in any given congressional term.

Finally, the structure of the media system is an important factor in understanding advocacy behavior (Mahoney 2008). Lobbyists who can capitalize on vibrant and broadreaching media systems to convey their policy messages have different opportunities than advocates who are faced with fragmented media markets divided by languages and audiences. Media-based lobbying tactics are logically linked to the nature of the media-system, a point which is typically missing in any single-polity study as the media system is a variable only in comparative research. With political communication so fundamental to modern democracies, the structure of the media system must be considered if we seek to understand why advocates behave as they do, and why they achieve or fail to achieve their goals.

Theoretically a great number of institutional factors and characteristics of a political system may have a bearing on advocacy behavior. Future research must consider such factors as 
the level of formal inclusion of interest groups into the policymaking process, the comparative strength of a system's branches of government and the multi-level structure of the polity. Considering the first, systems that reflect classic corporatist structures will lead interest groups to work closely with policymakers in a policy-creation give-and-take, with a stable set of actors called on for their expertise. Systems lacking formal interest-group consultation mechanisms will lead lobbyists to devise creative ways to get the attention of policymakers and have their policy message stand out from the cacophony of lobbying communications. Further, systems with highly formalized policymaking systems tend to result in widely recognized insiders and outsiders, a fact with important consequences for the behaviors of those groups considered to be “outsiders” (see Banaszak 2005).

A second institutional characteristic that will influence the advocacy behavior of lobbyists is the relative strength of the branches of governance—executive, legislative, judicial— in a political system. Executive-dominated political systems will drive lobbyists to focus on information exchange (Bouwen 2002), use arguments about policy feasibility, economic impact and other technical questions. Legislative-dominated systems on the other hand should lead lobbyists to focus on conveying information about electoral ramifications or the state of public opinion on the topic, and lobbying strategies will be devised to convey mass support. Advocates may or may not be able to use the courts to advance a political agenda, depending on the rules of the judicial system. In the United States for example, the courts were used successfully by the civil rights movement to advance minority rights which could not be done at the time through the legislative branch. Litigation by interest groups and the filing of amicus curiae by supportive interest groups were used as tools by resourceful activists. In other systems however, it may be more difficult for activists to advance their causes through the courts. The European Court of 
Justice for example is not the ideal venue for a pan-EU environmental NGO pressing for policy change through litigation. An aggrieved NGO cannot go directly to the ECJ, nor can it file anything akin to an amicus brief. It must take an offending party to court in the member state which upholds EU law, or if the government is the offender, request the European Commission to take action before the ECJ. Institutional rules dictate what opportunities are available to advocates to take legal action. In the EU, if activists want to utilize the legal route, they must do so at a lower level of governance (on the role of the ECJ, see Bouwen and McCowen 2007).

Lastly, the degree of multilevel governance of a political system also influences the advocacy strategies of lobbyists. Centralized systems will see the focus of advocacy in the capital, with interest groups spending their time, money and other resources targeted at central policymaking institutions. The more multi-level or federated a system, the more layers of governance exist for lobbyists to target. This may be used to their advantage if lobbyists can venue shop for a level that presents a more amicable environment in which to press their case. However, such structures can also present difficulties for advocates that need to communicate their concerns and ideas to a larger range of policymakers in different geographic locations and who likely have different policy preferences than their counterparts at other levels of governance. As the research above has demonstrated, especially in the EU context, the increasing Europeanization of some issues have had differential effects on certain types of groups, effectively disenfranchising local groups with limited opportunities to engage in Brussels-based lobbying and favoring others. Of course, different policy areas may be differentially affected by these processes.

Whether operating in a centralized system or the highest tier of a multi-level system, the tactics and argumentation of advocates will differ from those employed at lower levels of 
governance. The logic of Börzel's (2002) argument that suggests member states attempt to "upload" their policy preferences to the EU level so that they do not have to "download” EU policies that differ drastically from their original national policies could be extended to understanding interest groups. A national-level interest group that is lobbying for a policy before its national government but fails may in some cases be able to take the fight to the EU-level, and when operating at that new level it will use different arguments and tactics than back home. Because the constellation of forces may be different, it may win, and if it does, the policy will be "downloaded" to the national context. Similarly if a national group succeeds at home but wants to see its innovative policy exported to the whole of the European Union, it will again use different tactics and arguments, perhaps about the success of the policy at the member-state level, when operating at the higher tier of governance.

In short, multilevel systems present lobbyists with more complicated terrains to navigate and create opportunities as well as hurdles since there are not only more layers to cover but also different requirements at each tier. The ways in which different multi-level system arrangements might impact advocacy behavior is vast, and clearly requires more research. If scholars are correct and multi-level structures are becoming more common globally (Hooghe and Marks 2003), this research thread becomes all the more essential. Of course, such models cannot be assumed to work across the board, as there are important sectoral differences in the degree to which EU-involvement is even an option. Further, while there are interesting examples of political underdogs sometimes using these tactics to win surprising victories at a new level of a multi-level governance system, systematic empirical research would likely show a tremendous business advantage as issues are supra-nationalized. 
After institutions, the other set of contextual factors influencing advocacy behavior relates to the characteristics of the issues on which the groups are active. In contrast to the broad institutional structures discussed above, these factors of course differ from issue to issue within the same political system. Mahoney (2008) considers how issue salience, scope, conflict, and history affect a range of advocacy behaviors and decisions. The research shows that the nature of the issue is central to the decision-making of advocates when they devise their lobbying strategy. Again, the scope for theoretical expansion is significant.

The first issue characteristic that is clearly affects the behavior of lobbyists, but requires more systematic research, is the position of the governing party. Whether the party in power is supportive of an advocate's position affects whether the group is likely to mobilize for a fight, how it attempts to promote its position and the likelihood of success (see Michalowitz 2004). Government support should not be operationalized too simply however. Mere verbal or symbolic support for a policy position, without clear mobilization of resources, can mean little. The degree to which an issue is a priority for the government or relevant administrative actors may be more important in determining success than the stated position of the government. Groups spend much time, after all, trying to convince their allies in government to spend more time or energy on "their" issue.

Second, the composition of the various sides on an issue influences advocacy behavior. If a lobbyist has a large supporting coalition this can allow them to engage in a greater range of tactics and employ more expensive tactics (Baumgartner and Mahoney 2002). The size of a supporting coalition will also affect argumentation and framing as lobbyist incorporate the concerns of various allied groups into their argumentation repertoire. The size and strength of opposing interest groups or coalitions also drive lobbying behavior. Advocates assess the lay of 
the land when they consider mobilizing for a political fight. If they are up against a formidable opponent it could be enough to force them to back down or alter their advocacy strategy to be more effective in the face of a well-heeled or well-organized opposition. In sum, scholars must incorporate contextual factors including allies and opponents if we are to build proper models of lobbying strategies.

Third, the broader structure of the policy community is important to include in our research plans if we seek to understand they advocacy behavior of lobbyists and the outcome of their work. Lobbyists will make different advocacy decisions, and likely achieve different levels of success if they are working in a stable and collegial policy area, where they work iteratively with the same actors who share the same common language and agree on the goals of the policy than if they are active in a highly contentious policy area with changing actors vying for control over the direction, purpose and nature of policy creation.

Earlier work on advocacy behavior that focused on the importance of group characteristics in understanding their lobbying decisions was of course not misguided —who a group is, what they stand for, what resources they have at their disposal, and how they are organized are all critical pieces of information when trying to understand why advocates behave as they do when they seek to influence policymakers. Mahoney (2008) finds evidence that each of these factors influences what advocates do and to what effect.

While most aspects of interest groups have been recognized and studied, it is important to remember that groups do not often work alone, they have allies, both in government and outside, so when studying how a group's characteristics and resources impact their advocacy and their impact on the policymaking process it is also imperative that we also consider the resources and characteristics of the others involved in the same debate. 
When we consider concepts at any of these three levels-institutional, issue or interest group - it is critical to recognize and study them all as variables and to design variability on all levels into our research projects, to the extent possible. The level of formal inclusion of interest groups in the policymaking process varies from low to high, as do the degree of contestation, the number of allies and opponents, the degree of governmental support that a group enjoys, as do other factors of theoretical interest. Thinking of these concepts as variables that may take any value from low to high is more productive than labeling a system as corporatist or pluralist or a policy area as a policy monopoly or issue network, because these labels—which are often simply names for the end points of the continuum - are not only subjective and crude, but also typically mask substantial internal variation, forcing the researcher to combine several conceptually distinct questions into a single overarching label. Of all the characteristics of the literature on national styles of policymaking, this was perhaps the most troubling, and one that made the literature have the least international impact, as the various labels inevitably hid substantial commonality and variation on diverse concepts, giving in effect a new label for each combination of values on a series of conceptually distinct variables (and limiting the study to national or sectoral averages rather than issue-level observations) (see also Eising 2007, 2009). As the more recent literature has emerged, there are encouraging signs that scholars recognize the need for conceptual and analytic clarity.

\section{Conclusion}

Much has changed in the US and EU literatures on groups in the past generation; literatures that developed in parallel but separately have begun to converge. This is partly related to academic trends toward greater internationalization; it is partly generational as younger scholars, especially in Europe, are much more attuned to the international literature in their area (and anxious to 
publish in international rather than only in domestic publication venues); it is partly related to shifts in the institutional structures of policymaking within Europe as the EU has grown and so international and multi-level governance structures have become more relevant even to those interested in national level political processes. It certainly remains fair to say that most American scholars retain almost an entirely provincial perspective on the study of interest groups as they do in other fields. European scholars remain much more international in their focus than Americans, as a group, have ever been.

However, even in the US, as the literature on groups becomes more integrated and as scholars working in other countries demonstrate findings relevant to the established general theories, even Americans (such as ourselves) will take note. All this creates an unusual opportunity to foster the development of a truly comparative literature, one based on similar theoretical questions. The three examples we have given here are by no means exhaustive but rather are meant to illustrate the developments we have already observed and the promise of what is likely to develop further in the future. Systematic consideration of how group systems and the state co-evolve, how institutional structures affect the locus of policy activities by groups, and how institutional, issue-related, and group-specific factors affect the choices of lobbying behaviors by groups in any political system all show the promise of the development of a truly coherent and connected new literature on groups, one that is developing rapidly across many countries. Each of these three themes highlights the importance of recognizing that institutional structures are intimately related to the activities of organized interests. Comparative work on groups alerts us to the variation in governmental structures and how that variation drives advocacy decisions and policy outcomes. Our goal here has been to point to some of the most basic conceptual issues that will allow this literature to develop in a manner that is truly 
comparative and theoretically integrated so that studies done in different geographical contexts can be related to one another.

Inappropriate borrowing of concepts from one political system and their blind application to another, where their fit may be questionable, will certainly not help either literature move forward, so nothing that we write here should be taken as a suggestion that the literatures will necessarily be better merely because of convergence. There remain important differences between the functions of the US and European political systems, at the local, regional, national, and supranational levels and scholars must know the context of their work. However, many of the differences that characterized American and European scholarship on interest groups and lobbying in past generations were not justified by such differences. As the literatures engage more with each other, and as scholars design future projects, we see tremendous potential for the growth of an integrated cross-national literature on interest groups and lobbying. 


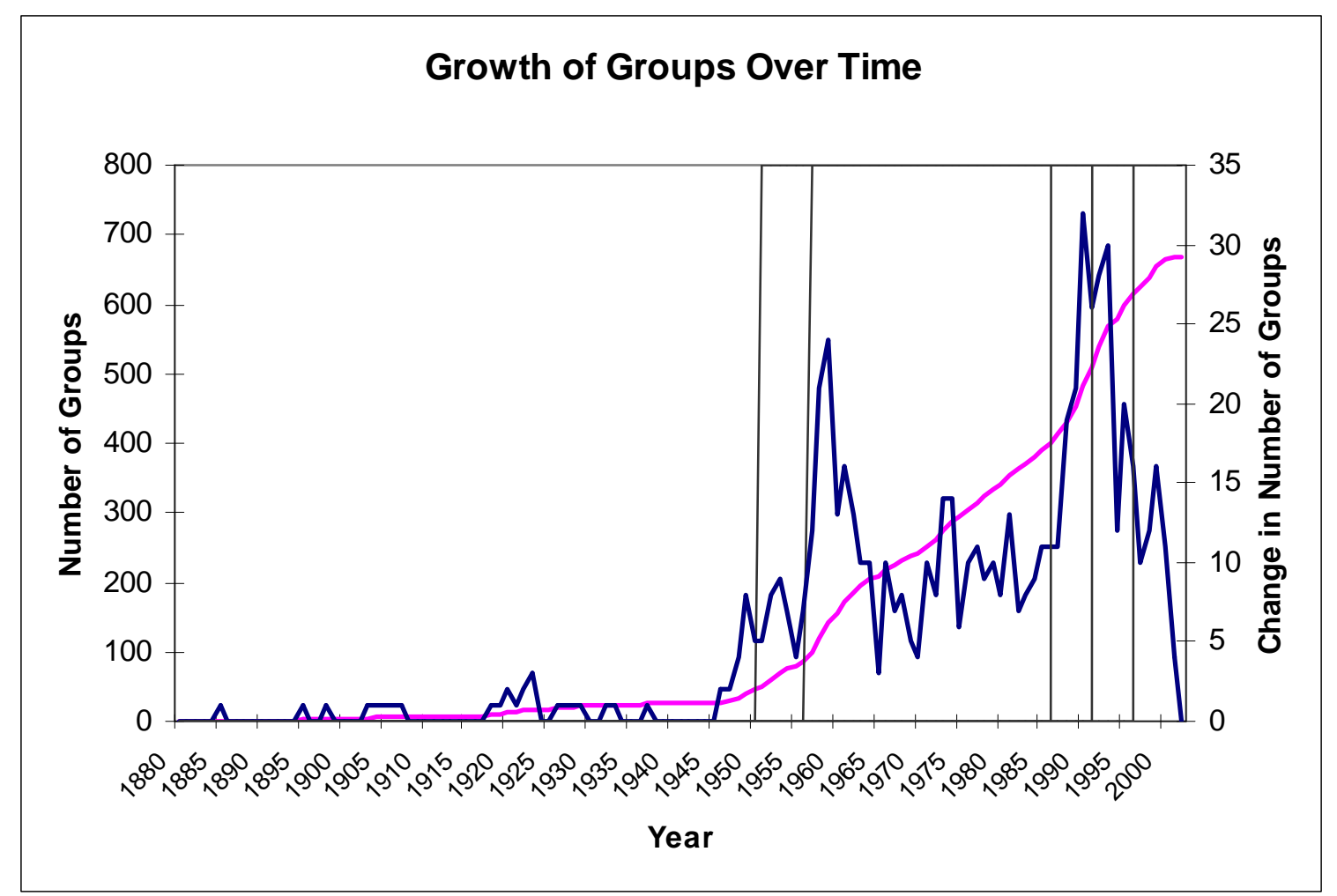

Figure 1. The Number of EU-Related Organizations Founded Over Time.

Note: The figure shows the number of organizations listed in the EU CONECCS Registry. Markers are 1951-ECSC, 1957-EEC, 1987-SEA, 1992-TEU, 1997-Amsterdam. The growing line shows the cumulative number of groups in existence and is measured on the left-hand scale. The more erratic series is the number of groups created in each year, and is measured on the right-hand scale. 


\section{References}

Banaszak, Lee Ann. 2005. "Inside and Outside the State: How Feminist Activists inside the Federal Bureaucracy Changed Policy." Paper presented at the annual meeting of the American Political Science Association, September 1-4, 2005, Washington, DC.

Baumgartner, Frank R. 2005. The Growth and Diversity of US Associations, 1956-2004:

Analyzing Trends using the Encyclopedia of Associations. Working paper, March 29.

Baumgartner, Frank R. and Bryan D. Jones. 1993. Agendas and Instability in American Politics.

Chicago: University of Chicago Press.

Baumgartner, Frank R. and Bryan D. Jones, eds. 2002. Policy Dynamics. Chicago: University of Chicago Press.

Baumgartner, Frank R., Virginia Gray, and David Lowery. 2009. Congressional Influence on State Lobbying Activity. Political Research Quarterly, forthcoming.

Baumgartner, Frank R., and Beth L. Leech. 1998. Basic Interests: The Importance of Groups in Politics and in Political Science. Princeton, N.J.: Princeton University Press.

Baumgartner, Frank R. and Christine Mahoney. 2004. Social Movements and the Rise of New Issues. In Routing the Opposition: Social Movements, Public Policy and Democracy. Eds. Helen Ingram,Valerie Jenness and David S. Meyer. Minneapolis: University of Minnesota Press, pp. 65-86.

Beyers, Jan. 2002. Gaining and Seeking Access: The European Adaptation of Domestic Interest Associations. European Journal of Political Research 41: 586-612.

Beyers, Jan. 2004. Voice and Access: Political Practices of European Interest Associations, European Union Politics 5 (2): 211-40. 
Beyers, Jan, Rainer Eising, and William Maloney. 2009. Much We Study, Little We Know? The Study of Interest Group Politics in Europe and Elsewhere. West European Politics. Forthcoming.

Boehmke, Frederick J. 2005. The Indirect Effect of Direct Legislation: How Institutions Shape Interest Group Systems. Columbus: The Ohio State University Press.

Börzel, Tanja A. 2002. Pace-setting, foot-dragging, and fence-sitting: member state responses to Europeanization,” Journal of Common Market Studies. 40:793-822

Bouwen, Pieter. 2002. 'Corporate Lobbying in the European Union: The Logic of Access’, Journal of European Public Policy 9(3): 365-90.

Bouwen, Pieter and McCown, Margaret. 2007. Lobbying versus Litigation: Political and Legal Strategies of Interest Representation in the European Union. Journal of European Public Policy 14, 3: 422-443.

Bush, Evelyn and Pete Simi. 2001. "European Farmers and Their Protests” In Doug Imig and Sidney Tarrow, eds. Contentious Europeans: Protest and Politics in an Emerging Polity. Lanham, MD: Rowman and Littlefield Publishers.

Campbell, Andrea L. 2005. How Policies Make Citizens: Senior Political Activism and the American Welfare State. Princeton, NJ: Princeton University Press.

Cater, Douglass. 1964. Power in Washington. New York: Random House.

Daviter, Falk. 2007. Policy Framing in the European Union. Journal of European Public Policy 14, 4 (June): 654-666.

Della Porta, Donatella., Hanspeter Kriesi and Dieter Rucht, eds., 1999. Social Movements in a Globalizing World, Basingstoke: MacMillan. 
Della Porta, Donatella and Marco Diani. 1999. Social Movements. An Introduction. Malden MA: Blackwell.

Eising, Rainer. 2004. 'Multilevel Governance and Business Interests in the European Union', Governance, Vol. 17, No. 2, pp. 211-245.

Eising, Rainer. 2007. “Interest Groups and Social Movements“, in Paolo Graziano and Maarten P. Vink (eds.) Europeanization: New Research Agendas, pp. 167-81. New York: Palgrave MacMillan.

Eising, Rainer. 2009. Patterns, what patterns? Clientela relations, pluralism, expert groups, and political contestation in the European Union. West European Politics. Forthcoming.

Fligstein, Neil and Alec Stone-Sweet. 2002. “Constructing Polities and markets: An Institutionalist Account of European Integration” American Journal of Sociology. 107: $1206-1243$

Fritschler, A. Lee. 1975. Smoking and Politics. 2d ed. Englewood Cliffs, NJ: Prentice-Hall.

Gerber, Elizabeth R. 1999. The Populist Paradox. Princeton: Princeton University Press.

Gray, Virginia, and David Lowery. 1996. The Population Ecology of Interest Representation. Ann Arbor: University of Michigan Press.

Gray, Virginia, Russell L. Hanson, Herbert Jacob. Eds. 1999. Politics In The American States: A Comparative Analysis, 7th ed. Washington, D.C.: CQ Press.

Grossman, Emiliano. 2004. Bringing politics back in: rethinking the role of economic interest groups in European integration. Journal of European Public Policy. 11, 4: 637-654.

Heclo, Hugh. 1978. Issue Networks and the Executive Establishment. In Anthony King, ed. The New American Political System. Washington: American Enterprise Institute. 
Hooghe, Lisbet and Gary Marks. 2003. Unraveling the Central State, But How? Types of MultiLevel Governance. American Political Science Review. 97 (2):233-243

Immergut, Ellen M. 1992. Health Politics: Interests and Institutions in Western Europe. New York: Cambridge University Press.

Jordan, G. and W. A. Maloney (1996) 'How bumble-bees fly: accounting for public interest participation', Political Studies, vol. 44: 4, pp. 668-685.

Jordan, G. and J. Richardson. 1987. Government and Pressure Groups in Britain. Oxford University Press: Oxford.

Katzenstein, Peter J. 1985. Small States in World Markets. Ithaca, NY: Cornell University Press. Keating, Michael and Liesbet Hooghe. 2001. By-passing the nation state? Regions and the EU policy process. In Jeremy Richardson, ed., European Union, Power and Policy-Making. 2nd edition. New York: Routledge.

Klandermans, Bert, Marga de Weerd, José Manuel Sabucedo and Mauro Rodriguez. 2001. Framing Contention: Dutch and Spanish Farmers. In Doug Imig and Sidney Tarrow, eds., Contentious Europeans: Protest and Politics in an Emerging Polity. Lanham, MD: Rowman and Littlefield Publishers.

Kriesi, H., R. Koopmans, J.W. Duyvendak and M.G. Giugni, (1992) ‘New Social Movements and Political Opportunities in Western Europe', European Journal of Political Research, Vol. 22, pp. 219-244.

Knoke, David, Franz Urban Pappi, Jeffrey Broadbent, Yutaka Tsujinaka. 1996. Comparing Policy Networks: Labor Politics in the U.S., Germany, and Japan. New York: Cambridge University Press. 
Leech, Beth L., Frank R. Baumgartner, Timothy M. LaPira, and Nicholas A. Semanko. 2005. Drawing Lobbyists to Washington: Government Activity and the Demand for Advocacy. Political Research Quarterly 58, 1 (March): 19-30.

Lehmbruch, Gerhard, and Philippe C. Schmitter, eds. 1982. Patterns of Corporatist Policy Making. London: Sage.

Mahoney, Christine. 2004. "The Power of Institutions: State and Interest-Group Activity in the European Union,” European Union Politics. Volume 5 (4): 441-466.

Marks, Gary and Doug McAdam. 1996. "Social Movements and the Changing Structure of Political Opportunity in the European Union.” West European Politics 19(2): 249-278.

Marks, Gary and Doug McAdam. 1999. 'On the Relationship of Political Opportunities to the Form of Collective Action: The Case of the European Union', in: D. della Porta, H. Kriesi and D. Rucht (eds), Social Movements in a Globalizing World, Basingstoke: MacMillan, pp. 97-111.

Marks, Gary, Richard Haesly and Heather A.D. Mbaye. 2001. What do subnational offices think they are doing in Brussels? Paper presented at the European Community Studies Association meeting. Madison Wisconsin, May 31-June 3.

Mayhew, David. 1974. Congress: The Electoral Connection. New Haven: Yale University Press.

Mayntz, Renate, and Fritz W. Scharpf. 1975. Policy-Making in the German Federal Bureaucracy. Amsterdam: Elsevier

Mettler, Suzanne. 2005. Soldiers into Citizens: The G.I. Bill and the Making of the Greatest Generation. New York: Oxford University Press. 
Michalowitz, Irina. 2004. EU Lobbying - Principals, Agents and Targets: Strategic interest intermediation in EU-policy-making. Munster: Lit Verlag.

Miller, Lisa L. 2008. The Perils of Federalism: Poor People and the Politics of Crime Control. New York: Oxford University Press.

Peterson, Paul. 1981. City Limits. Chicago: University of Chicago Press.

Peterson, Paul. 1995. The Price of Federalism. Washington D.C.: Brookings Institution Press.

Pralle, Sarah. 2006. Branching Out and Digging In: Environmental Advocacy and Agenda Setting. Washington DC: Georgetown University Press.

Princen, Sebastiaan, and Bart Kerremans. 2009. Opportunity Structures in the EU Multilevel System. West European Politics. Forthcoming.

Schmitter, Philippe C. 1974. Still the Century of Corporatism? The Review of Politics 36: 85131.

Schmitter, Philippe C., and Gerhard Lehmbruch, eds. 1979. Trends Towards Corporatist Intermediation. Beverly Hills: Sage.

Schneider, Volker, W. Streeck, J. Grote and J. Visser,, eds. 2006. Governing Interests: Business Associations Facing Internationalization. London: Routledge.

Shipan, Charles R., and Craig Volden. 2006. Bottom-up Policy Federalism: The Spread of Antismoking Laws from U.S. Cities to States. American Journal of Political Science 50 (October): 825-843.

Skocpol, Theda. 1992. Protecting Soldiers and Mothers: The Political Origins of Social Policy in the United States. Cambridge: Harvard University Press.

Smith, M.J. 1993. Pressure, power and policy: State autonomy and policy networks in Britain and United States. New York: Harvester Wheatsheaf. 
Wessels, Bernhard. 2004. "Contestation potential of interest groups in the EU: emergence, structure, and political alliances” In European Integration and Political Conflict: Citizens, Parties, Groups, ed. Gary Marks and Marco Steenbergen (Cambridge: Cambridge University Press). P195-215.

Wessels, Wolfgang. 1997. “An Ever Closer Fusion? A Dynamic Macropolitical View on Integration Processes” Journal of Common Market Studies. Vol 35(2) 267-299.

\section{Author contact information}

Christine Mahoney is corresponding author:

346 Eggers Hall

Moynihan European Research Centers

Moynihan Institute of Global Affairs

Maxwell School

Syracuse University

Syracuse, NY 13244

chmahone@maxwell.syr.edu

\section{Acknowledgements:}

Baumgartner would like to acknowledge the support of NSF awards 0111611 and 0111224 and his collaborators Bryan Jones, John McCarthy, Beth Leech, Jeff Berry, Marie Hojnacki, and David Kimball. Sciences Po (Cevipof) in Paris and the Camargo Foundation in Cassis France provided work support during periods when this paper was written. Thanks also to colleagues William Maloney, Jan Beyers, David Coen, Grant Jordan, Emiliano Grossman, and Rainer Eising for comments. 